\title{
Thermocells Driven by Phase Transition of Hydrogel Nanoparticles
}

\author{
Benshuai Guo ${ }^{1}$, Yu Hoshino ${ }^{1 *}$, Fan $\mathrm{Gao}^{2}$, Keisuke Hayashi ${ }^{2,3}$, Yoshiko Miura ${ }^{1}$, Nobuo Kimizuka ${ }^{2,3}$, Teppei \\ Yamada $^{2,3^{*}}$ \\ ${ }^{1}$ Department of Chemical Engineering, Graduate School of Engineering, Kyushu University, Motooka 744, Nishi-ku, Fukuoka 819- \\ 0395, Japan \\ ${ }^{2}$ Department of Chemistry and Biochemistry, Graduate School of Engineering, Kyushu University, Motooka 744, Nishi-ku, Fukuoka \\ 819-0395, Japan \\ ${ }^{3}$ Center for Molecular Systems, Kyushu University \\ *yhoshino@chem-eng.kyushu-u.ac.jp, ${ }^{*}$ teppei343@gmail.com \\ ${ }^{\text {*Contributed equally }}$ \\ Supporting Information Placeholder
}

\section{Supporting information}




\section{Materials}

The following chemicals and materials were obtained from commercial sources and used as received. $N, N^{\prime}$ methylenebisacrylamide $\quad$ (BIS), $\quad$ cetyltrimethylammonium $\quad$ bromide $\quad$ (CTAB), $\quad N-[3-$ (dimethylamino)propyl]methacrylamide (DMAPM) were obtained from Tokyo Chemical Industry Co., Ltd. HCl, hexane, sodium chloride, acrylic acid (AAc), poly(acrylic acid), sodium dodecyl sulfate (SDS), azobisisobutyronitrile (AIBN) and 4,4'-azobis(4-cyanovaleric acid) (V-501) were obtained from Watanabe Pure Chemical Industry Co., Ltd. $\mathrm{NaOH}$ was obtained from Kanto Chemical Co., Inc.; $N$-isopropylacrylamide (NIPAM) was obtained from Wako Pure Chemical Industries, Co., Ltd. and recrystallized from hexanes. The dialysis tube (MWCO 12,000-14,000 Da, Spectrum Laboratories, Inc.) was washed with water prior to use. Cation exchange beads (Muromac C1002-H, Muromachi Chemicals, Inc.) and anion exchange beads (Muromachi Technos Co., Ltd., A2004-OH) were pretreated with aqueous $\mathrm{HCl}(1 \mathrm{M})$ and then washed with excess water. The water used in this study was purified using a Direct-Q Ultrapure Water System (Merck, Ltd.).

\section{Synthesis of AAc NPs}

AAc NPs was synthesized according to the literature ${ }^{48}$. NIPAM (93 mol\%, $3.28 \mathrm{~g}$ ), BIS (2 mol\%, $96 \mathrm{mg}$ ), AAc (5 mol\%, $285 \mathrm{mg}$ ), and SDS (180 mg) were dissolved in $100 \mathrm{~mL}$ of water, which resulted in a total monomer concentration of 312 $\mathrm{mM}$. The $\mathrm{pH}$ of the solution was adjusted with an $\mathrm{HCl}$ solution to 2.6 which was monitored by a $\mathrm{pH}$ meter (S50 SevenMulti, Mettler Toledo Co. Ltd.). The reaction mixture was then degassed with nitrogen flushing for $30 \mathrm{~min}$. Following the addition of V-501 (19.3 mg in $1.96 \mathrm{~mL}$ of DMSO), the polymerization was carried out at $70{ }^{\circ} \mathrm{C}$ for $3 \mathrm{~h}$ under a nitrogen atmosphere. The polymerized solution was purified by dialysis against an excess amount of water (changed more than 3 times a day) for 2 days. Traces of counter anions were removed by strong cation exchange beads (Muromac C1002-H, Muromachi Chemicals, Inc.). The beads were filtered out after exchanging for $1 \mathrm{~h}$.

The yield of NPs was determined by measuring the weight of NPs obtained by lyophilization of a part of the dialyzed solution $(79.4 \%)$. The concentration of NPs $\left(27.05 \mathrm{mg} \mathrm{mL}^{-1}\right)$ treated by the lyophilization method was determined by measuring the moisture absorption and mass after reaching the humidity balance in the air.

Lyophilized powder of NPs was dissolved in $\mathrm{CD}_{3} \mathrm{OD}\left(50 \mathrm{mg} \mathrm{mL}{ }^{-1}\right)$. Proton nuclear magnetic resonance $\left({ }^{1} \mathrm{H}\right.$ NMR $)$ experiments were conducted on a JEOL JNM-ECP400 instrument at $25^{\circ} \mathrm{C}$. The trace of the surfactant remaining in the NPs was determined from the results of NMR (Fig. S1).

VPT behavior of the sample was confirmed by a dynamic light scattering (DLS) instrument (Zetasizer Nano, Malvern Instruments Limited) using the ion-exchanged solutions. The solution was equilibrated at each temperature for 2 min prior to the measurement. Fig. S4 shows a plot of the hydrodynamic diameter obtained by DLS as a function of temperature. The average diameters of the polymer chains decreased during the VPT, which corresponded to the dehydration of the polymer chains above approximately $30^{\circ} \mathrm{C}$. 
The concentration of the carboxylic acid of the NPs was estimated to be $335.6 \mu \mathrm{mol} / \mathrm{g}$ by acid-base titration using aqueous $\mathrm{NaOH}$ at 30 and $70{ }^{\circ} \mathrm{C}$ (Fig. S2). According to the mass concentration of NPs $\left(27.05 \mathrm{mg} \mathrm{mL}^{-1}\right)$, the concentration of carboxyl groups in the original solution of NPs can be calculated $(9.08 \mathrm{mM})$. The $\mathrm{pH}$ of the solution was adjusted to be the same as apparent $\mathrm{p} K_{\mathrm{a}}$ of the acids in NPs by adding 0.5 equivalents of $\mathrm{NaOH}$.

\section{Synthesis of DMAPM NPs}

NIPAM (93 mol\%, $3.28 \mathrm{~g}$ ), BIS (2 mol\%, $96 \mathrm{mg}$ ), DMAPM (5 mol\%, $0.28 \mathrm{~mL}$ ), and CTAB (73 mg) were dissolved in $100 \mathrm{~mL}$ of water, which resulted in a total monomer concentration of $312 \mathrm{mM}$. The $\mathrm{pH}$ of the solution was adjusted with $\mathrm{NaOH}$ solution to 10.6 which was monitored by a $\mathrm{pH}$ meter (S50 SevenMulti, Mettler Toledo Co. Ltd.). The reaction mixture was then degassed with nitrogen flushing for $30 \mathrm{~min}$. Following the addition of AIBN (11.3 mg in $2 \mathrm{~mL}$ of $\mathrm{MeOH}$ ), the polymerization was carried out at $70^{\circ} \mathrm{C}$ for $3 \mathrm{~h}$ under a nitrogen atmosphere. The polymerized solution was purified by dialysis against an excess amount of water (changed more than 3 times a day) for 2 days. Traces of counter cations were removed by strong anion exchange beads. The beads were filtered out after exchanging for $1 \mathrm{~h}$. The yield of NPs was determined by measuring the weight of NPs obtained by lyophilization of a part of the dialyzed solution $(84.6 \%)$. The concentration of NPs $\left(30.76 \mathrm{mg} \mathrm{mL}^{-1}\right)$ treated by the lyophilization method was determined by measuring the moisture absorption and mass after reaching the humidity balance in the air.

Lyophilized powder of NPs was dissolved in $\mathrm{CD}_{3} \mathrm{OD}\left(50 \mathrm{mg} \mathrm{mL}^{-1}\right) .{ }^{1} \mathrm{H}$ NMR experiments were conducted on a JEOL JNM-ECP400 instrument at $25^{\circ} \mathrm{C}$. The trace of the surfactant remaining in NPs was determined by the results of NMR (Fig. S1).

VPT behavior of the sample was confirmed by a DLS instrument (Zetasizer Nano, Malvern Instruments Limited) using the ion-exchanged solutions. The solution was equilibrated at each temperature for $2 \mathrm{~min}$ prior to the measurement. Fig. S2 shows a plot of the hydrodynamic diameter obtained by DLS as a function of temperature. The concentration of the amine of NPs was estimated by acid-base titration using aqueous $\mathrm{HCl}$ at 30 and $70{ }^{\circ} \mathrm{C}$ (Fig. S2) to be $390.3 \mu \mathrm{mol} / \mathrm{g}$. According to the mass concentration of NPs $\left(30.76 \mathrm{mg} \mathrm{mL}^{-1}\right)$, the concentration of amino groups in the original solution of NPs can be calculated $(12.0 \mathrm{mM})$.The $\mathrm{pH}$ of the solution was thereby adjusted to be the same as apparent $\mathrm{p} K_{\mathrm{a}}$ of ammonium ions in the NPs by adding 0.5 equivalents of $\mathrm{HCl}$. 
(a)

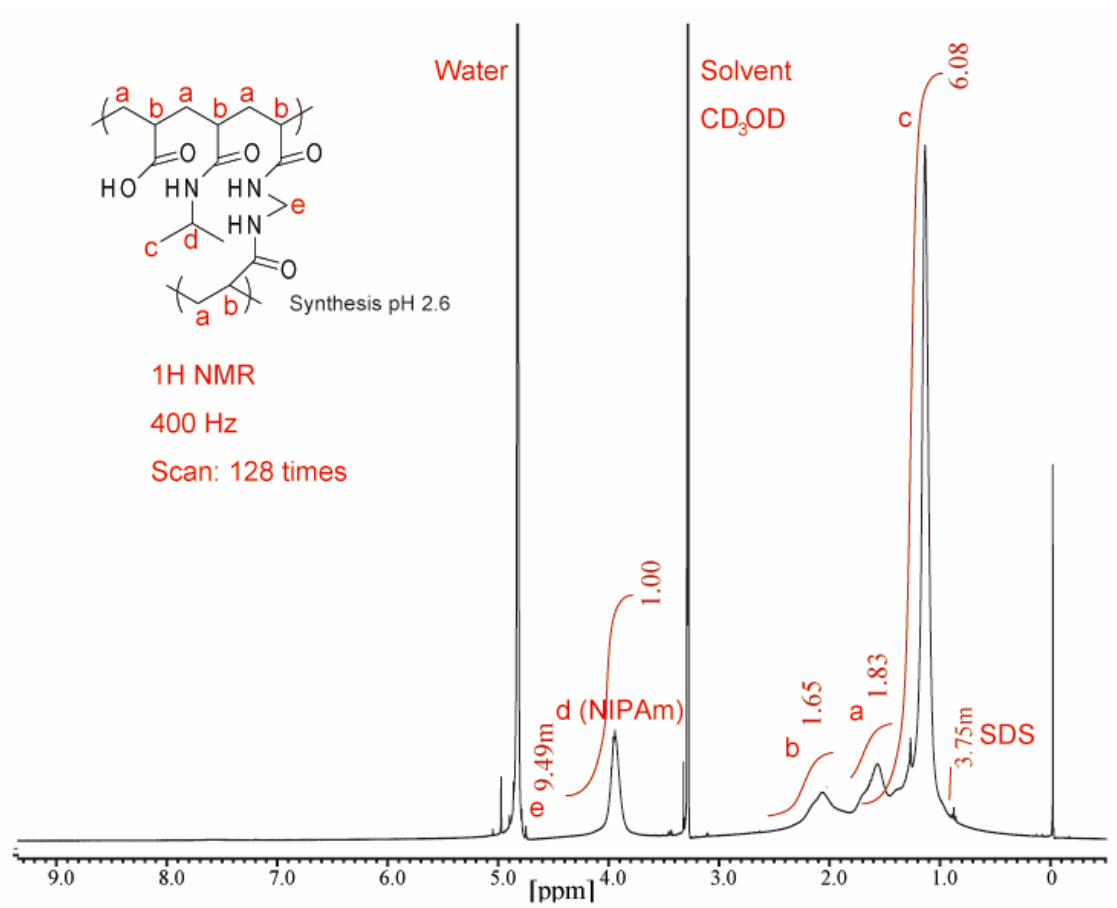

(b)

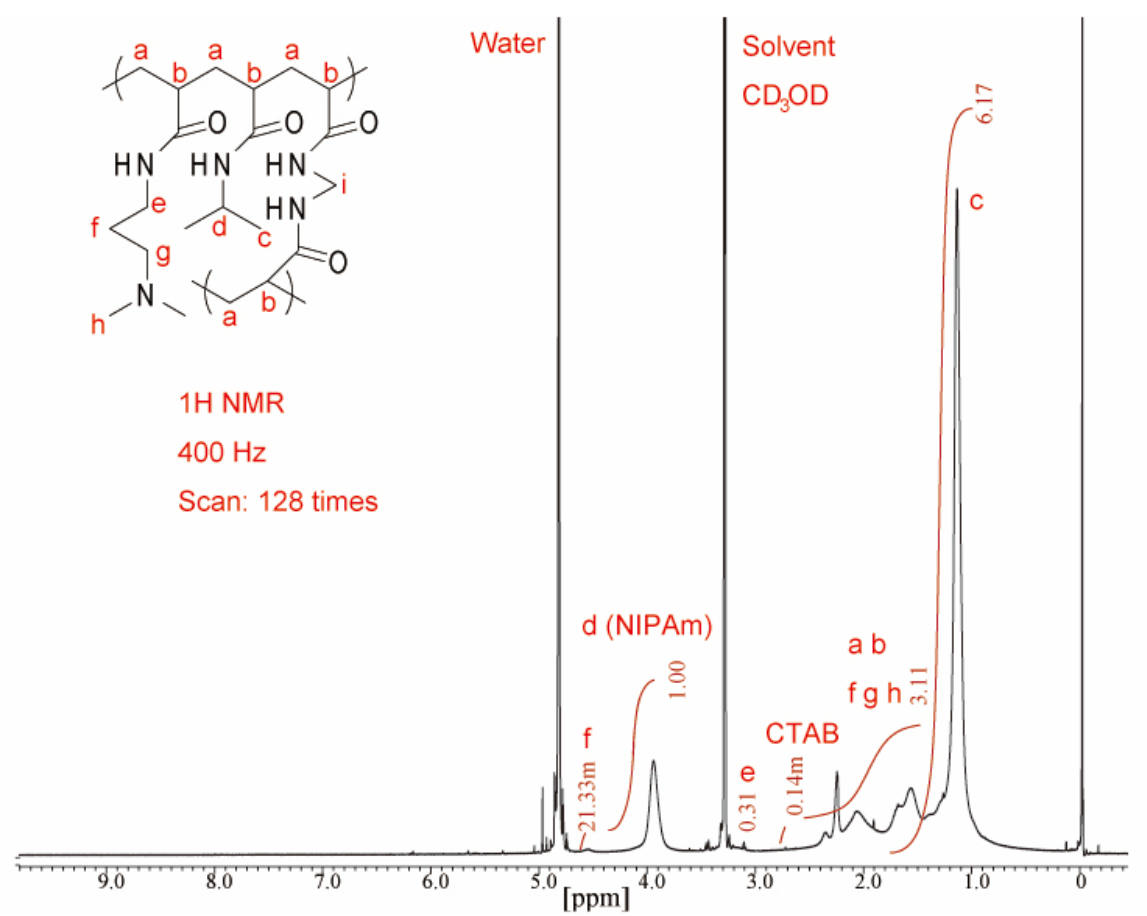

Figure S1. ${ }^{1} \mathrm{H}$ NMR results of (a) AAc NPs and (b) DMAPM NPs. 
(a)

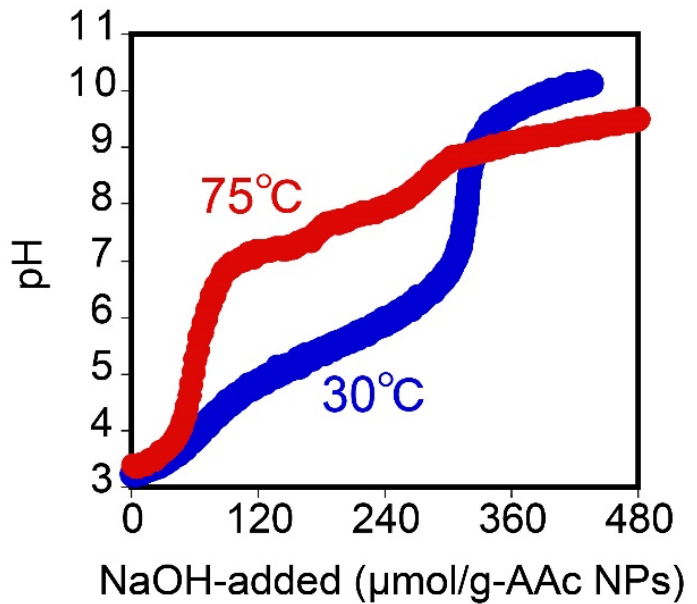

(b)

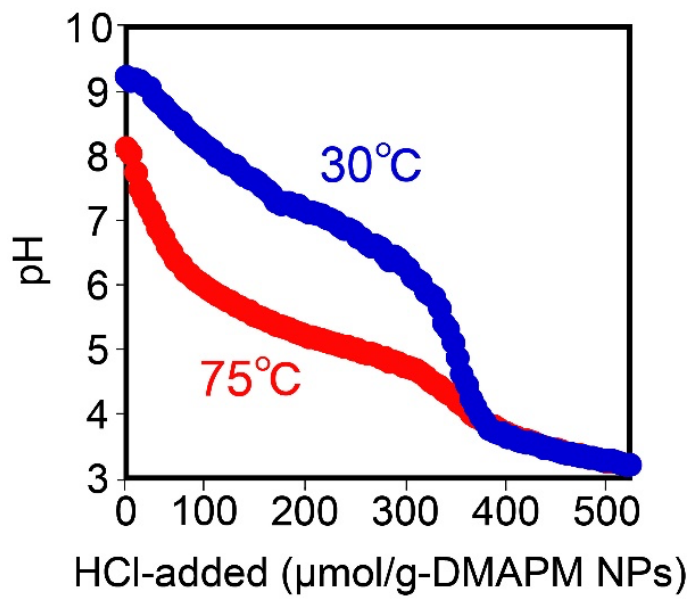

Figure S2. Titration curves of (a) AAc NPs $(4.0 \mathrm{mg} / \mathrm{mL})$ and (b) DMAPM NPs $(4.0 \mathrm{mg} / \mathrm{mL})$ at 30 (blue) and $75^{\circ} \mathrm{C}$ (red). The horizontal axis is the amount of added $\mathrm{NaOH}$ and $\mathrm{HCl}$ for AAc NPs and DMAPM NPs, respectively. By determining the neutralization point, the amount of carboxy and amino groups contained in NPs can be calculated.

\section{DLS analysis}

The hydrodynamic diameter of NPs was estimated with a dynamic light scattering (DLS) instrument. The solution was equilibrated at each temperature for $2 \mathrm{~min}$ prior to the measurement. Fig. S3 shows a size distribution of each NPs. Fig. S4 shows a plot of the hydrodynamic diameter obtained by DLS as a function of temperature. Apparently, the average diameters of the polymer chains decreased above $30^{\circ} \mathrm{C}$, which corresponded to the structural change of the polymer chains by VPT. 
(a)

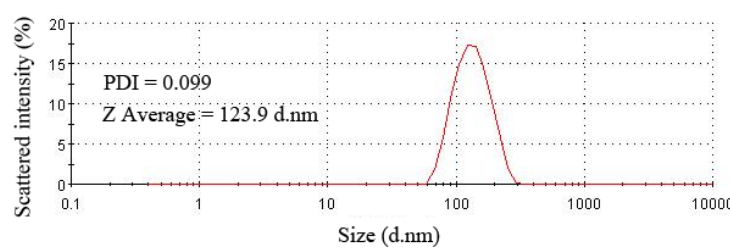

(c)

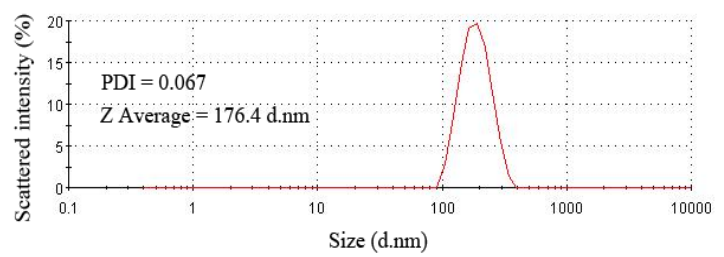

(b)

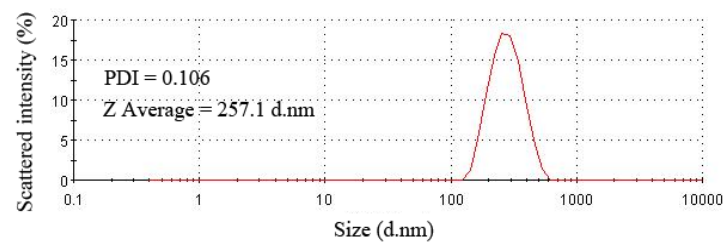

(d)

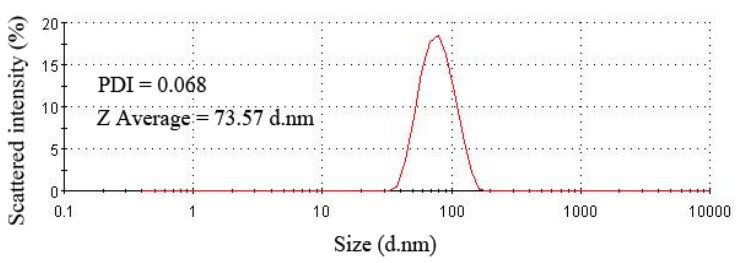

Figure S3. DLS particle diameter distribution of (a) AAc NPs $(1.0 \mathrm{mg} / \mathrm{mL})$ at $20^{\circ} \mathrm{C}$, (b) AAc NPs $(1.0 \mathrm{mg} / \mathrm{mL})$ at $50^{\circ} \mathrm{C}$, (c) DMAPM NPs $(1.0 \mathrm{mg} / \mathrm{mL})$ at $20^{\circ} \mathrm{C}$ and (d) DMAPM NPs $(1.0 \mathrm{mg} / \mathrm{mL})$ at $50^{\circ} \mathrm{C}$.

(a)

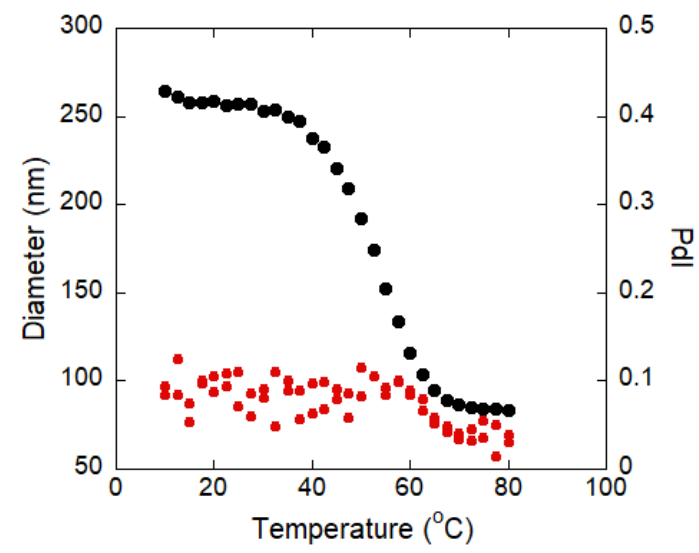

(b)

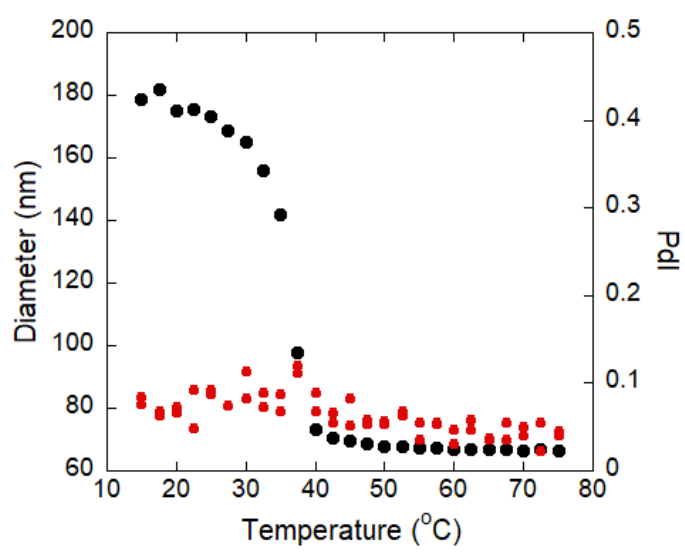

Figure S4. Change of mean-diameter of (a) AAc NPs $(1.0 \mathrm{mg} / \mathrm{mL})$ and (b) DMAPM NPs $(1.0 \mathrm{mg} / \mathrm{mL})$ estimated from DLS measurements with the change in temperature. 


\section{Measurement of Thermoelectric Voltage}

Experimental apparatus for voltage measurement was made up of the following components. $10 \mathrm{~mL}$ of electrolyte solutions were put into water jacket glass cells $\left(\Phi 25.6 \mathrm{~mm}^{*}\right.$ h $\left.50 \mathrm{~mm}\right)$ (Fig. S5b). Two mix stirrers $(\Phi 5 \mathrm{~mm} * 20 \mathrm{~mm})$ were added in each half cell. Each cell was covered with a 3-hole teflon cap, where a platinum working electrode was immersed into the electrolyte solution. A $25 \mathrm{~cm}$ silicon tube salt bridge containing agar gel with $3 \mathrm{M}$ potassium chloride solution was inserted through 3-hole teflon cap to connect two cells. And a thermocouple was inserted into the electrolyte solution in each cell. Temperature of each cell was controlled separately by using an external thermostatic device to circulate water into the water jacket of each cell. The terminals of the source meter 2401 (Keithley) were connected to the electrodes of each cell. DC voltage measurement mode $(\mathrm{mV})$ for displaying the voltage was set. Before the measurement was started, the carbon dioxide and oxygen in the electrolyte solution were removed by nitrogen bubbling for 30 minutes to prevent $\mathrm{pH}$ change and oxidation of quinhydrone. After confirming that the inside of both cells was stabilized at $20^{\circ} \mathrm{C}$., gradually raise the temperature of the jacket water of one cell until it reached $70{ }^{\circ} \mathrm{C}$. The difference in temperature and the voltage between the hot and cold cell sides was plotted, and the Se was estimated from the slope of the plot.

Various concentrations of quinhydrone and NPs were dissolved into milli-Q water (AAc NPs ([AAc $]=2 \mathrm{mM},[\mathrm{NaOH}]$ $=1 \mathrm{mM})$, poly $(\mathrm{NIPAM}) \mathrm{NPs}(5.9 \mathrm{mg} / \mathrm{mL}), \operatorname{poly}(\mathrm{AAc})(5.9 \mathrm{mg} / \mathrm{mL})$ and DMAPM NPs $([\mathrm{DMAPM}]=2 \mathrm{mM},[\mathrm{HCl}]=$ $1 \mathrm{mM})$ ). The $\mathrm{pH}$ of each cell was adjusted by the addition of half an equivalent of $\mathrm{NaOH}$. Various concentrations of $\mathrm{KCl}$ were added to improve ionic conductivity. For the cell without NPs, an aqueous solution of quinhydrone (5.6 mM) and $\mathrm{HCl}$ was added to adjust the $\mathrm{pH}$ to 4.2 .

(a)

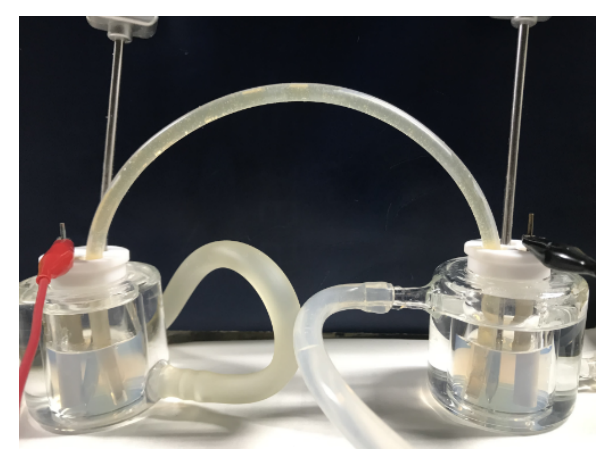

(b)

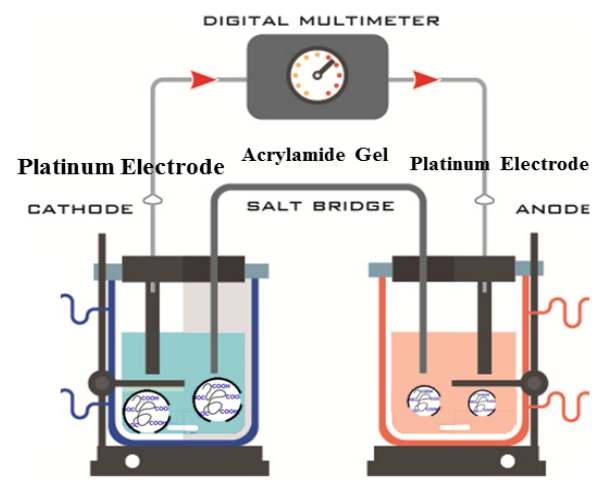

Figure S5. (a) Photograph of a bridged thermocell design for open circuit voltage mesurement. (b) Diagram of salt the bridged thermocell. 
(a)

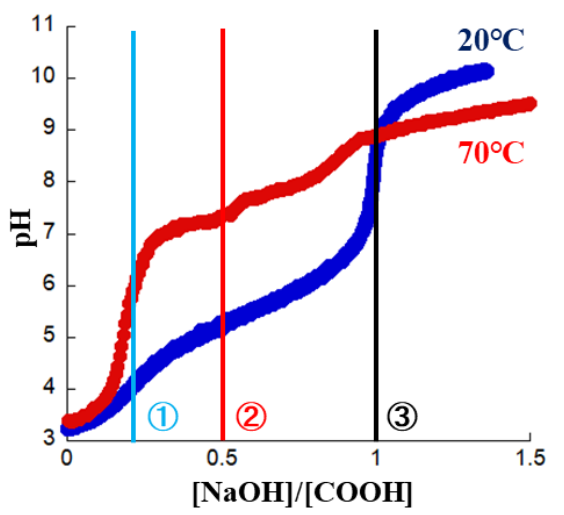

(c)

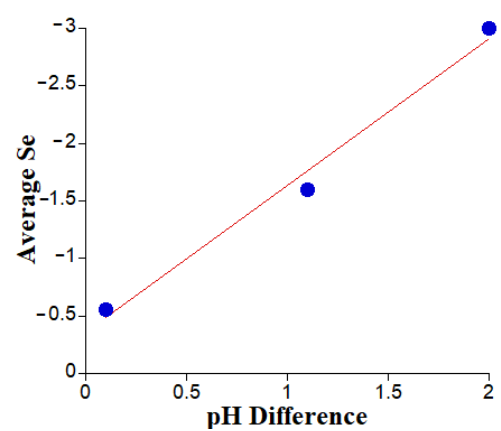

(b)

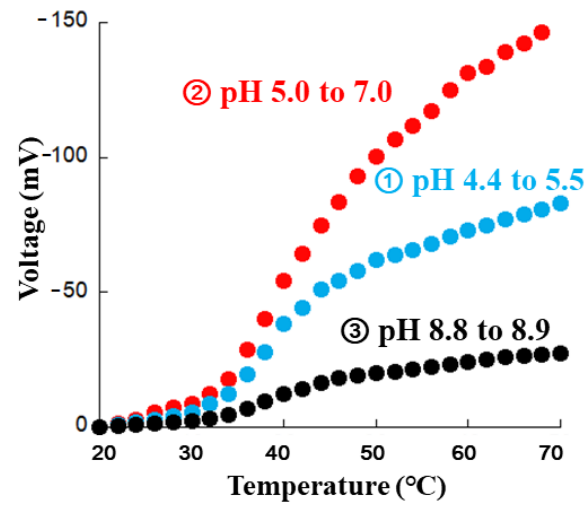

Figure S6. In order to establish importance of $\mathrm{pH}$ shift on the generation of the large $S_{e}$ value, two quinhydrone thermocells with AAc NPs which $\mathrm{pH}$ is adjusted to be $\mathrm{pH} 4.4,5.0$ and 8.8 at $20^{\circ} \mathrm{C}$ were prepared by adding appropriate amount of $\mathrm{NaOH}$. (a) Titration curves of AAc NPs at $20^{\circ} \mathrm{C}$ and $70^{\circ} \mathrm{C}$. Appropriate amount of $\mathrm{NaOH}$, shown as (1) (2) (3), was added in order to prepare thermocells which pH is $4.4,5.0$ and 8.8 , respectively at $20^{\circ} \mathrm{C}$. (b) Open circuit voltage of quinhydrone $(5.6 \mathrm{mM})$ themocells constructed with AAc NPs ([AAc] $=2 \mathrm{mM}$ ) and $0.4 \mathrm{mM}$ ((1)blue), 1 $\mathrm{mM}$ (2)red) and $2 \mathrm{mM}$ (3) black) of $\mathrm{NaOH}$. The slope of the curves corresponds to the Seebeck coefficient $\left(S_{\mathrm{e}}\right)$. The average $S_{e}$ of $-1.6 \mathrm{mV} \mathrm{K}^{-1}$ and $-0.6 \mathrm{mV} \mathrm{K}^{-1}$ was observed upon the heating process of (1) and (3), respectively, which were significantly smaller than that of the cell (2) which $\mathrm{pH}$ was adjusted to be equal to the $\mathrm{p} K_{\mathrm{a}}$ of AAc in the NPs ( $\mathrm{pH}=$ 5.0, $S_{e}=-3.0 \mathrm{mV} \mathrm{K}^{-1}$ ). (c) The average $S_{\mathrm{e}}$ of thermocells as a function of $\mathrm{pH}$ difference. Temperatures of cold and hot electrodes are $20^{\circ} \mathrm{C}$ and $70^{\circ} \mathrm{C}$, respectively. 


\section{Measurement of Thermoelectric Current}

The experimental apparatus for the thermocell measurements was made up of the following components. A home-made $\mathrm{H}$-shape glass tube with an inner diameter of $20 \mathrm{~mm}$ (Fig. S7b) was used as the thermocell and $35 \mathrm{~mL}$ of electrolyte solutions were added into it. Each side of the container was soaked in coolant or a heater, respectively, to control the temperature of each side separately. Platinum wires $(1 \mathrm{~mm}$ in diameter and $80 \mathrm{~mm}$ in length) were washed by soaking them in concentrated sulfuric acid and these were rinsed with ultrapure water before use. Two platinum wires were immersed into the electrolyte solution, and the current between the wires were measured with a source meter 2401 (Keithley). The temperature at both sides of the cell was monitored during the measurement with two thermometers (TM-201). The temperature of the cold side of the container was kept at approximately $20^{\circ} \mathrm{C}$ and the solution was magnetically stirred during the measurement.

Various concentrations of quinhydrone and NPs were dissolved into milli-Q water. The $\mathrm{pH}$ of each cell was adjusted by the addition of half an equivalent of $\mathrm{NaOH}$. Various concentrations of $\mathrm{KCl}$ were added to improve ionic conductivity. For the cell without NPs, an aqueous solution of quinhydrone $(5.6 \mathrm{mM})$ and $\mathrm{HCl}$ was added to adjust the $\mathrm{pH}$ to 4.2 .

(a)

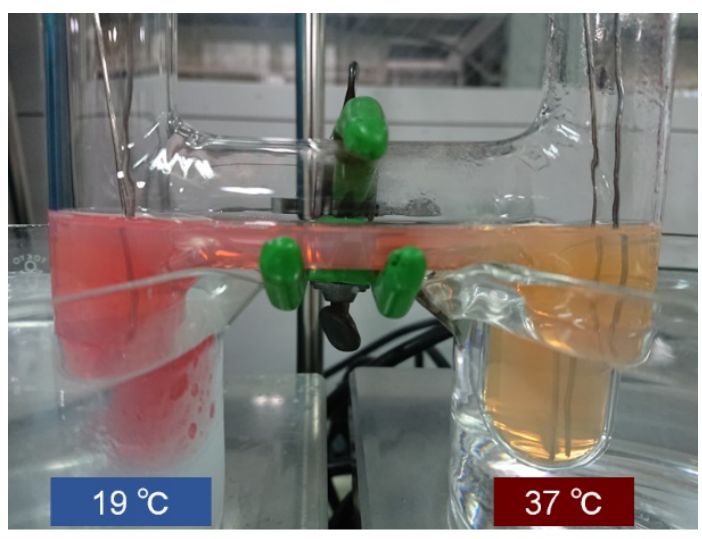

(b)

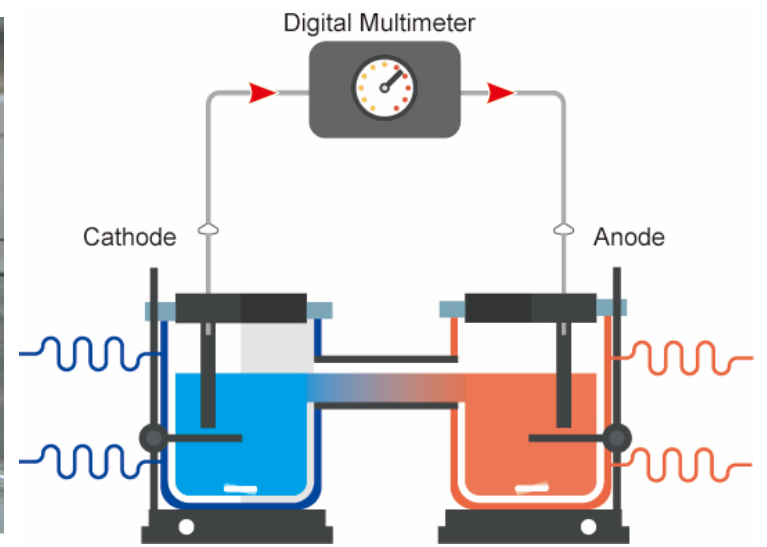

Figure S7. (a) Photograph of $\mathrm{H}$-shape thermocell consisting AAc NPs $(5.9 \mathrm{mg} / \mathrm{mL},[\mathrm{AAc}]=2 \mathrm{mM},[\mathrm{NaOH}]=1 \mathrm{mM})$ for current measurement. Methyl orange was added to the cell to visualize the $\mathrm{pH}$ difference between both sides of the cell. (b) Diagram of the H-shape cell. 


\section{Measurements of Electrical and Thermophysical Property}

The ionic conductivity of the electrolyte solutions was measured by an electric conductivity meter (SevenMulti Dual Digital Meter with Conductivity and $\mathrm{pH}$ Modules, Mettler Toledo) with a Mettler-Toledo Conductivity TDS/SAL/Resistivity Module. The thermal conductivity of the samples was measured by a transient plane source technique by a hot disk thermal constants analyzer (Hot Disk TPS 500, Kyoto Electronics) with a \#7577 sensor at ambient temperature. $40 \mathrm{~mL}$ of electrolytes were used, and each measurement was repeated 10 times with a 1-min interval.

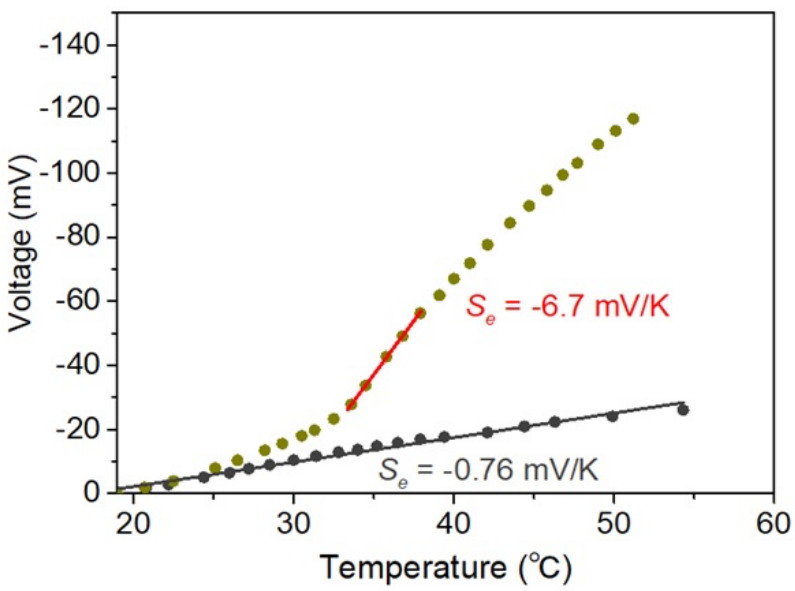

Figure S8. Open circuit voltage of quinhydrone $(5.6 \mathrm{mM})$ themocells constructed without NPs (black), and with AAc NPs $([\mathrm{AAc}]=2 \mathrm{mM},[\mathrm{NaOH}]=1 \mathrm{mM})$ (green) measured by H-shape cell. The slope of the curves corresponds to the Seebeck coefficient $\left(S_{\mathrm{e}}\right)$. 


\section{Control experiments using poly(AAc) and poly(DMAPM)}

Poly(acrylic acid) (MW 25000) was dissolved in water to prepare poly(AAc) solution. Poly(DMAPM) was synthesis by simple radical polymerization. DMAPM $(312 \mathrm{mM}, 5.6 \mathrm{~mL})$ was dissolved in $100 \mathrm{~mL}$ of water. The $\mathrm{pH}$ of the solution was adjusted with $\mathrm{HCl}$ solution to 7.8 which was monitored by a $\mathrm{pH}$ meter (S50 SevenMulti, Mettler Toledo Co. Ltd.). The reaction mixture was then degassed with nitrogen flushing for $60 \mathrm{~min}$. Following the addition of APS ( $22.8 \mathrm{mg}$ in $1 \mathrm{~mL}$ of water), the polymerization was carried out at $60^{\circ} \mathrm{C}$ for $22 \mathrm{~h}$ under a nitrogen atmosphere. The polymerized solution was purified by dialysis against an excess amount of water (changed more than 3 times a day) for 2 days. Finally, a light yellow transparent poly(DMAPM) aqueous solution can be obtained. Experimental apparatus for voltage measurement was constructed same as the experiment of AAc NPs and DMAPM NPs voltage measurement. The open-circuit voltage and the $\mathrm{pH}$ of polymer solution were measured during the heating of one of the cells from $20^{\circ} \mathrm{C}$ to $70{ }^{\circ} \mathrm{C}$. The two polymer aqueous solutions without VPT behavior did not show obvious temperature-dependent $\mathrm{pH}$ changes and large $S_{\mathrm{e}}$

(a)

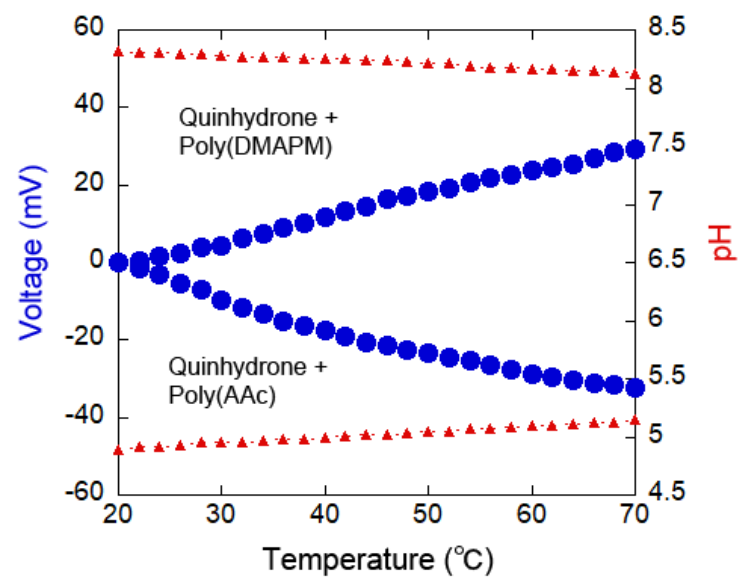

(b)

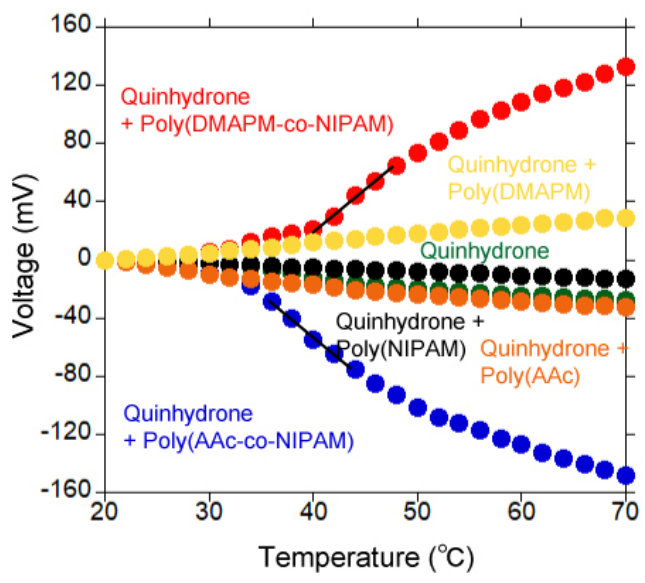

Figure S9. (a) $V-T$ and $p H-T$ plots of thermocell consisting of $5.6 \mathrm{mM}$ quinthdrone with $5.9 \mathrm{mg} / \mathrm{mL}$ poly(AAc) and poly(DMAPM). (b) Open circuit voltage of quinhydrone ( $5.6 \mathrm{mM})$ themocells constructed without NPs (green), and with AAc NPs $([\mathrm{AAc}]=2 \mathrm{mM},[\mathrm{NaOH}]=1 \mathrm{mM})($ blue $)$, DMAPM NPs $([\mathrm{DMAPM}]=2 \mathrm{mM},[\mathrm{HCl}]=1 \mathrm{mM})($ red $)$, poly (NIPAM) NPs $(5.9 \mathrm{mg} / \mathrm{mL})$ (black), poly(AAc) $(5.9 \mathrm{mg} / \mathrm{mL})$ (orange) and poly (DMAPM) $(5.9 \mathrm{mg} / \mathrm{mL})$ (yellow). 
(a)

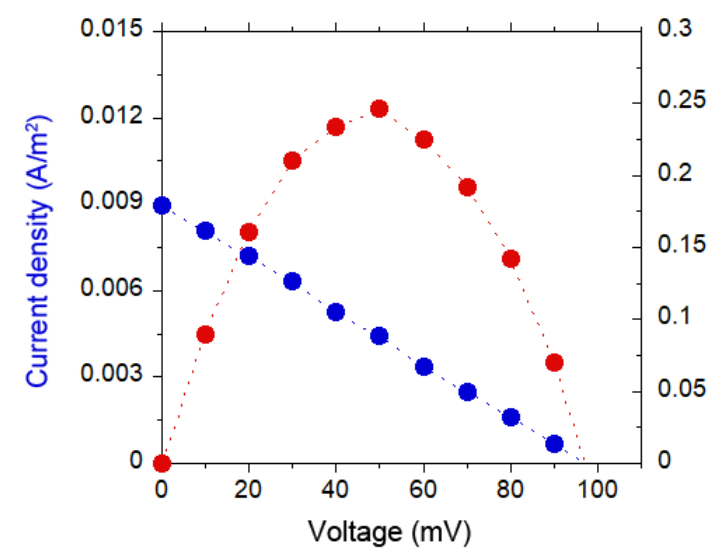

(b)

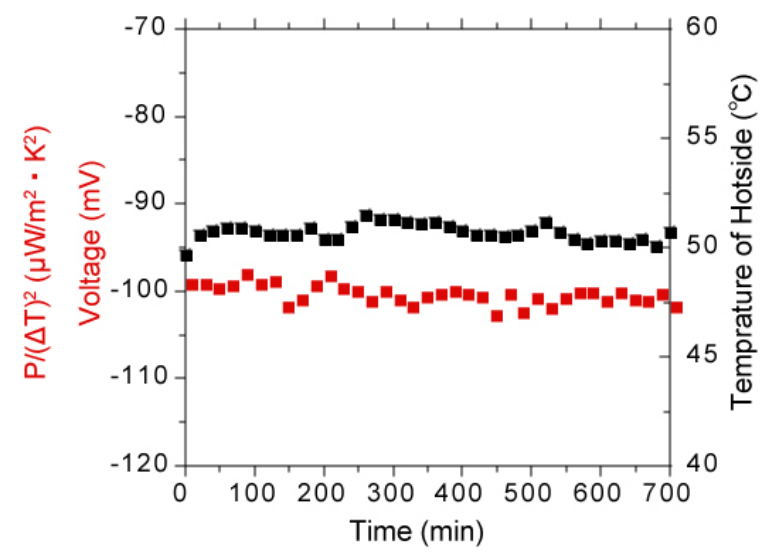

Figure S10. (a) $I-V$ and $P-V$ plots of thermocell consisting of quinthdrone $(5.6 \mathrm{mM})$ with DMAPM NPs $(5.9 \mathrm{mg} / \mathrm{mL}$, $[\mathrm{DMAPM}]=2 \mathrm{mM},[\mathrm{HCl}]=1 \mathrm{mM})$. (b) Time dependency of thermocell voltage, respectively. Temperatures of cold and hot cells were $20^{\circ} \mathrm{C}$ and $50^{\circ} \mathrm{C}$, respectively.

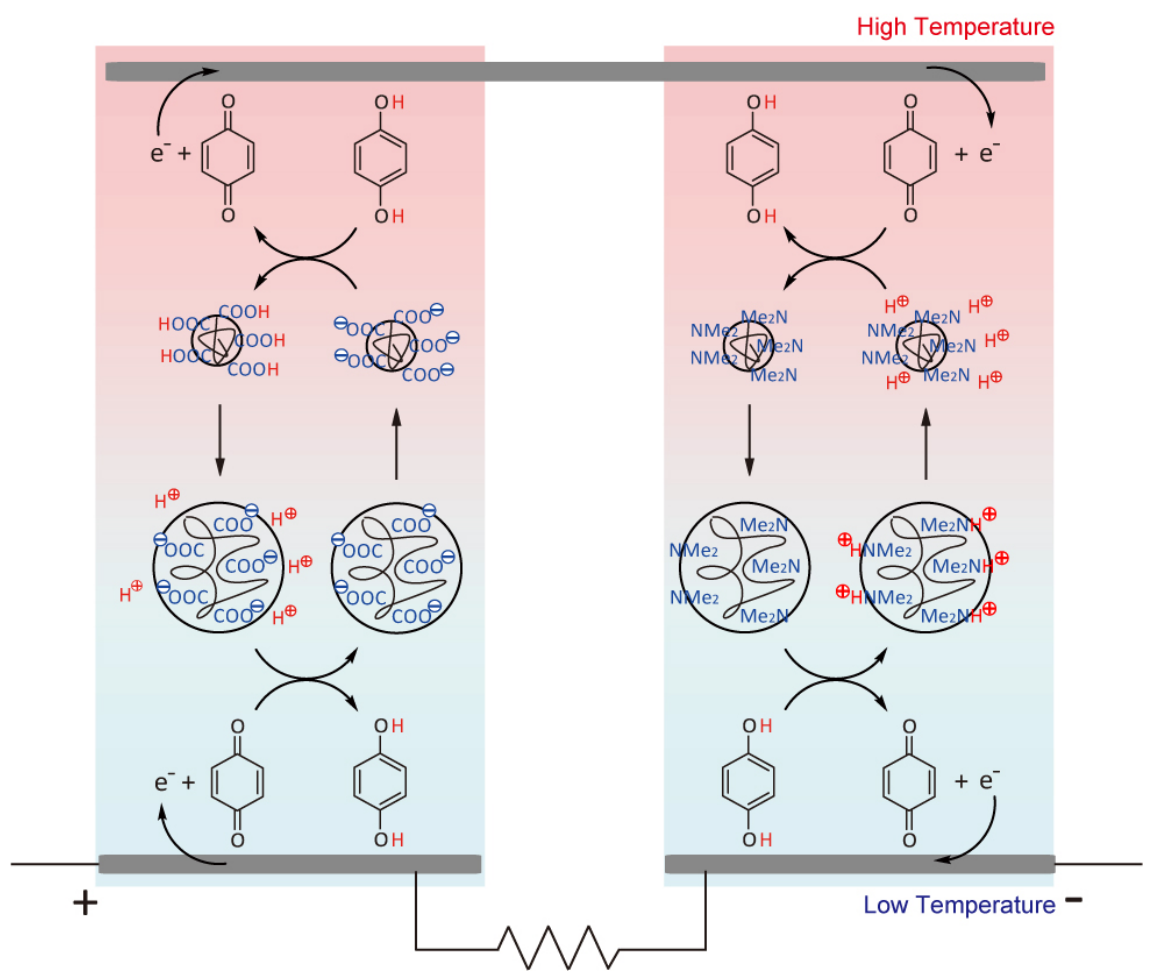

Figure S1 1. Schematic illustration of the p-and n-type thermocell consisting of thermo-responsive NPs and their serial $\pi$-type connection. 
Table S1. Seebeck coefficients of liquid phase thermocells with various redox species

\begin{tabular}{|c|c|c|}
\hline & $\begin{array}{c}S_{\mathrm{e}} \\
\left(\mathrm{mV} \mathrm{K}^{-1}\right)\end{array}$ & Ref \\
\hline$[\mathrm{Fe}(\mathrm{CN}) 6]^{3-/ 4-}($ water/guanidinium/urea $)$ & -4.2 & 1 \\
\hline $\mathrm{I}^{-} / \mathrm{I}_{3}^{-}(\alpha-\mathrm{CD}$ in Water $+\mathrm{KCl})$ & 1.98 & 2 \\
\hline $\mathrm{Co}^{2+/ 3+}(\mathrm{py}-\mathrm{pz})_{3}$ & 2.36 & 3 \\
\hline$\left[\mathrm{Fe}(\mathrm{CN})_{6}\right]^{3-/ 4-}($ Water $)$ & -1.60 & 4 \\
\hline $\mathrm{I}^{-} / \mathrm{I}_{3}^{-}$(Water) & 0.68 & 5 \\
\hline Quinhydrone & -0.63 & 6 \\
\hline $\mathrm{I}^{-} / \mathrm{I}_{3}^{-} / \mathrm{I}_{5}^{-}\left(\mathrm{Me}_{18-}-\alpha-\mathrm{CD}\right.$ in Water $)$ & 1.90 & 7 \\
\hline $\mathrm{Fe}^{2+} / \mathrm{Fe}^{3+}$ & 1.76 & 8 \\
\hline $\mathrm{Co}^{2+/ 3+}(\mathrm{bpy})$ in $\mathrm{MPN}$ & 2.2 & 9 \\
\hline
\end{tabular}

\section{Measurements of Zeta potential of NPs solution}

The Zeta potential of the NPs solutions was measured by by a dynamic light scattering (DLS) instrument (Zetasizer Nano, Malvern Instruments Limited) using zeta potential measurement mode.

Table S2. Zeta potential of NPs solution at different temperature and $\mathrm{pH}$ values

\begin{tabular}{|c|c|c|c|c|}
\hline \multirow[t]{2}{*}{ Sample Name } & \multirow{2}{*}{$\begin{array}{l}\text { NPs Concentration } \\
\qquad(\mathrm{mg} / \mathrm{mL})\end{array}$} & \multirow{2}{*}{$\begin{array}{l}\text { Solution } \\
\qquad \mathrm{pH}\end{array}$} & \multicolumn{2}{|c|}{ Zeta Potential $(\mathrm{mV})^{[\mathrm{b}]}$} \\
\hline & & & $20^{\circ} \mathrm{C}$ & $70^{\circ} \mathrm{C}$ \\
\hline AAc NPs & 1.0 & $7.0^{[\mathrm{a}]}$ & -5.95 & -11.4 \\
\hline DMAPM NPs & 1.0 & $7.0^{[\mathrm{a}]}$ & 0.173 & 0.567 \\
\hline
\end{tabular}

${ }^{[a]}$ Measured in $10 \mathrm{mM}$ phosphate buffer $(\mathrm{pH}=7.0)$ solutions.

${ }^{[b]}$ Average \pm standard deviation of three sequential measurements. Data may include inaccuracy due to polydispersity 


\section{REFERENCES}

(1) Duan, J.; Feng, G.; Yu, B.; Li, J.; Chen, M.; Yang, P.; Feng, J.; Liu, K.; Zhou, J. Aqueous Thermogalvanic Cells with a High Seebeck Coefficient for Low-Grade Heat Harvest. Nat. Commun. 2018, 9 (1), 5146.

(2) Serpe, M. J.; Yarmey, K. A.; Nolan, C. M.; Lyon, L. A. Doxorubicin Uptake and Release from Microgel Thin Films. Biomacromolecules 2005, 6 (1), 408-413.

(3) Al-Masri, D.; Dupont, M.; Yunis, R.; MacFarlane, D. R.; Pringle, J. M. The Electrochemistry and Performance of Cobalt-Based Redox Couples for Thermoelectrochemical Cells. Electrochim. Acta 2018, 269, 714-723.

(4) Quickenden, T. I.; Vernon, C. F. Thermogalvanic Conversion of Heat to Electricity. Sol. Energy 1986, 36 (1), 63-72.

(5) Abraham, T. J.; MacFarlane, D. R.; Pringle, J. M. Seebeck Coefficients in Ionic Liquids -Prospects for ThermoElectrochemical Cells. Chem. Commun. 2011, 47 (22), 6260-6262.

(6) Lewis, E. A.; Hansen, L. D. Thermodynamics of Binding of Guest Molecules to $\alpha$-and $\beta$-Cyclodextrins. J. Chem. Soc. Perkin Trans. 2 1973, 2 (15), 2081-2085.

(7) Liang, Y.; Yamada, T.; Zhou, H.; Kimizuka, N. Hexakis(2,3,6-Tri-:O-Methyl)- $\alpha$-Cyclodextrin-I 5- Complex in Aqueous I- / $\mathrm{I}^{3-}$ Thermocells and Enhancement in the Seebeck Coefficient. Chem. Sci. 2019, 10 (3), 773-780.

(8) Kim, J. H.; Lee, J. H.; Palem, R. R.; Suh, M. S.; Lee, H. H.; Kang, T. J. Iron (II/III) Perchlorate Electrolytes for Electrochemically Harvesting Low-Grade Thermal Energy. Sci. Rep. 2019, 9 (1), 8706.

(9) Abraham, T. J.; MacFarlane, D. R.; Pringle, J. M. High Seebeck Coefficient Redox Ionic Liquid Electrolytes for Thermal Energy Harvesting. Energy Environ. Sci. 2013, 6 (9), 2639-2645. 